\title{
Viewing The Quality Of Early Childhood Education From The Organizing Point Of View And Classroom Management
}

\author{
Luthfatun Nisa', Ria Astuti \\ Received: 01032021 / Accepted: 21062021 / Published online: 30062021 \\ (C) 2021 Association of Indonesian Islamic Kindergarten Teachers Education Study Program
}

\begin{abstract}
Abstrak Penelitian ini bertujuan untuk menilik ulang kualitas sebuah lembaga Pendidikan Anak Usia Dini (PAUD) yang dilihat dari sudut pandang pengorganisasian iklim dan dalam proses pengelolaan kelas, dikarenakan kualitas pendidikan dipengaruhi oleh iklim organisasi dan kualitas proses pendidikan, namun dalam pelaksanaannya dua hal tersebut kurang menjadi perhatian dalam proses pengorganisasian sebuah lembaga pendidikan khsusunya PAUD sehingga perlu dikaji lebih dalam terkait pentingnya pengorganisasian iklim dan pengelolaan keas dalam menentukan kualitas lembaga PAUD. Penelitian ini menggunakan metode penelitian kualitatif dengan pendekatan kajian kepustakaan (library research), yaitu pengumpulan data diperoleh dari berbagai literatur yang selanjutnya dikaji dan dianalisa secara mendalam yang selanjutnya ditarik kesimpulan. Dalam penelitian ini akan diuraikan bagaimana identifikasi permasalahan yang ada dilingkungan sekolah, bagaimana pengorganisasian iklim dan pengelolaan kelas dapat memberikan dampak pada kualitas pendidikan, dan bagaimana solusi yang ditawarkan untuk meningkatkan kualitas pengorganisasian iklim dan pengelolaan kelas. Sehingga dari penelitian ini diharapkan dapat memberikan alternatif solusi untuk diterapkan dalam proses pembelajaran khusunya dalam pengorganisasian iklim dan pengelolaan kelas.
\end{abstract}

Kata kunci: kualitas PAUD, pengorganisasian iklim sekolah, pengelolaan kelas

\begin{abstract}
This study aims to review the quality of an early childhood education institution (ECE) from the perspective of climate organization and in the classroom management process, because the quality of education is influenced by the organizational climate and the quality of the educational process, but in its implementation these two things are less of a concern. in the process of organizing an educational institution, especially ECE, so it needs to be studied more deeply related to the importance of climate organization and health management in determining the quality of ECE institutions. This study uses a qualitative research method with a library research approach, which is the collection of data obtained from various literatures which are then studied and analyzed in depth and then conclusions are drawn. In this study, we will describe how to identify problems that exist in the school environment, how climate organization and classroom management can have an impact on the quality of education, and how solutions are offered to improve the quality of climate organizing and classroom management. So that this research is expected to provide alternative solutions to be applied in the learning process, especially in climate organization and classroom management.
\end{abstract}

Keywords: ECE quality, organizational climate, organizational classroom 


\section{Pendahuluan}

Pendidikan Anak Usia Dini (PAUD) merupakan salah bentuk program pendidikan yang memfokuskan pada pertumbuhan dan perkembangan serta pemberian stimulasi pada anak usia lahir sampai dengan 6 tahun. Masa ini dianggap sebagai masa emas (golden age) dikarenakan hampir $80 \%$ pertumbuhan dan perkembangan anak terjadi pada usia ini. Sehingga bukan maklum lagi jika PAUD dianggap penting dikarenakan usia dini merupakan bekal dimasa selanjutnya, dan pondasi utama terjadi dalam usia dini. Salah satu usaha untuk mengoptimalkan pertumbuhan dan perkembangan anak adalah melalui pendidikan.

Pendidikan adalah usaha sadar yang dilakukan untuk mengembangkan potensi peserta didik dengan tetap mempertimbangkan karakteritik perserta didik menuju pertumbuhan dan perkembangan yang optimal. Sedangkan pendidikan nasional berfungsi mengembangkan kemampuan dan membentuk watak serta peradaban bangsa yang bermartabat dalam rangka mencerdaskan kehidupan bangsa. Pendidikan nasional bertujuan untuk mengembangkan potensi peserta didik agar menjadi manusia yang beriman dan bertakwa kepada Tuhan Yang Maha Esa, berakhlak mulia, sehat, berilmu, cakap, kreatif, mandiri, dan menjadi warga negara yang demokratis serta bertanggungjawab, berdasarkan pada Undang-undang Nomor 20 tahun 2003.

Salah satu unsur penting didalam pendidikan adalah proses komunikasi yang terbangun didalamya, baik dari sisi manajemen maupun dari sisi pembelajaran yang keduanya melibatkan pendidik, tenaga kependidikan, dan peserta didik. Pengorganisasian ini disebut dengan pengorganisasian iklim atau lingkungan dalam pendidikan. Menurut Sergiovanni (Suryaman, 2004: 67) "school climate has obvious implications for improving the quality of work life for those who in school". Pengorganisasian iklim dan juga pengelolaan kelas penting dilakukan untuk menciptakan suasana belajar yang kondusif dan bermakna sehingga dapat menciptakan pendidikan khususnya PAUD yang berkualitas. Pendidikan berkualitas tidak hanya dilihat dari hasil, berupa prestasi akademik peserta didik, namun hal yang juga penting adalah proses. Yaitu proses dalam membentuk peserta didik menjadi berprestasi, yakni melalui pendidikan yang berkualitas dengan menciptakan iklim dan pengorganisasian kelas yang baik.

Kualitas pendidikan merupakan hal penting dalam penyelenggaraan pendidikan. Dalam sebuah literatur dijelaskan bahwa terdapat hubungan yang positif anak pra-sekolah pada perkembangan sosial dan perkembangan akademisnya karena mereka memiliki pengalaman pendidikan dengan kualitas tinggi walaupun mereka lahir dari keluarga yang memiliki tingkat ekonomi rendah (National Institute of Child Health and Human Development Early Child Care Research Network, 2000. National Reaserch Council, 2001. Schweinhart, 2005). Seperti, anakanak yang lahir dari tingkat ekonomi rendah dan sekolah dengan kualitas program yang tinggi, memiliki prestasi yang lebih tinggi dan memiliki kesiapan akademik yang tinggi kurang lebih 1,5 kali lebih tinggi dibanding anak yang tidak masuk jenjang pra-sekolah atau anak yang sekolah dengan kualitas program yang rendah. Sehingga dapat dikatakan kualitas akademik anak dipengaruhi oleh kualitas program pendidikannya. Pendidikan anak usa dini dikatakan memiliki kualitas yang tinggi jika memenuhi struktur indikator (ukuran kelompok kecil, jumlah murid sebanding dengan rasio guru, pendidikan guru pada level tinggi) (Scarr, Eisenberg, \& Deater-Deckard, 1994). Dan dalam proses pelaksanaan guru memiliki hubungan dan interaksi positif dengan anak, dan pengembangan kurikulum serta aktivitas yang tepat untuk perkembangan anak.

Kualitas pendidikan dipengaruhi oleh iklim organisasi dan kualitas proses pendidikan. Iklim organisasi didefinisikan sebagai suasana yang unik yang dibangun dalam organisasi tersebut. Selain itu iklim organisasi juga diartikan dari segi model perilaku sosio-ekologis yang lebih menekankan pada sifat interaktif antar manusia dengan lingkungnnya, serta berkaitan dengan sikap, kepercayaan, dan nilai individu di lingkungan kerja tertentu, serta kualitas hubungan mereka dengan lingkungan kerja tempat mereka bekerja. Iklim organisasi disekolah (Bloom, 2010) meliputi dan berkaitan dengan profesionalitas, dukungan supervisor, sistem penghargaan, pengambilan keputusan, orientasi tugas, dan inovasi pembelajaran. selain itu iklim organisasi juga meliputi hubungan guru dengan pengelola, hubungan guru dengan guru, dan 
hubungan guru dengan siswa. Di sekolah, iklim organisasi cenderung mempengaruhi perilaku dan sikap guru yang nantinya mempengaruhi kualitas kelas dan hasil prestasi anak.

Namun dalam prakteknya ditemukan bahwa diantara para guru dengan pengalaman mengajar yang lebih banyak lebih kurang toleran pada kebijakan iklim organisasi dengan kualitas rendah, baik dari segi praktik maupun hubungan dengan sesama pendidik. Sedangkan guru yang masih bersetatus baru kurang peduli dengan iklim organisasi tempat mereka mengajar. Guru lebih banyak memikirkan diri mereka sendiri sebagai guru baru, dan ketidak sesuaian iklim ini dapat berdampak pada proses pengajaran, kepedulian diri, bermasalah dengan tugas sekolah.

Menariknya masalah tersebut lebih sedikit muncul pada sekolah yang memiliki guru dengan pendidikan yang lebih tinggi. Dan guru dengan pendidikan yang lebih rendah lebih bergantung pada rekan kerja atau pimpinan dalam membangun lingkungan kelas mereka dalam proses pembelajaran serta dukungan kelas mereka seperti, membutuhkan bantuan dalam proses perencanaan, pengumpulan materi, serta manajemen kelas.

Dibeberapa negara termasuk Indonesia pendidikan anak usia dini yang didalamnya anakanak dengan latar belakang ekonomi rendah sekolah yang ditempatipun cenderung memiliki kualitas pendidikan yang rendah, dan banyak intervensi program yang ditujukan untuk meningkatkan kualitas kelas dengan menyediakan pelatihan pengembangan profesional guru, namun sering tidak menunjukkan pengingkatan kualitas yang signifikan, dan belum secara signifikan mempengaruhi perkembangan anak. Dan hal ini belum benar-benar menyelesaikan masalah yang ada. Sehingga harus ditemukan solusi strategi yang efektif untuk untuk meningkatkan iklim organisasi yang dapat berdampak pada kualitas proses kelas.

Sehingga, dalam penelitian ini akan diuraikan bagaimana identifikasi permasalahan yang ada dilingkungan sekolah, bagaimana pengorganisasian iklim dan pengelolaan kelas dapat memberikan dampak pada kualitas pendidikan, dan bagaimana solusi yang ditawarkan untuk meningkatkan kualitas pengorganisasian iklim dan pengelolaan kelas. Sehingga dari penelitian ini diharapkan dapat memberikan alternatif solusi untuk diterapkan dalam proses pembelajaran khusunya dalam pengorganisasian iklim dan pengelolaan kelas.

\section{Metode}

Metode yang digunakan dalam penelitian ini adalah penelitian kualitatif dengan jenis penelitian kepustakaan (library research), dengan proses pengumpulan informasi baik berupa catatan atau data-data deskriptif, yang selanjutnya diklasifikasikan, dianalisis, dan dideskripsikan. Data-data dikumpulkan melalui hasil telah jurnal, buku, makalah atau berbagai sumber yang mendukung melalui telaan pustaka. Semua sumber tersebut dikumpulkan untuk mendukung dalam pengakajian tentang kualitas PAUD yang ditilik dari sisi pengorganisasian iklim dan pengelolaan kelas.

\section{Hasil Penelitian}

PAUD merupakan pendidikan yang mendasar dan strategis dalam pembangunan sumber daya manusia. Sesuai pasal 28 Undang-undang nomor 20 tahun 2003 tentang Sistem Pendidikan Nasional, PAUD telah ditempatkan sejajar dengan pendidikan lainnya. Berdasarkan Undangundang tersebut dapat dikatakan secara yuridis PAUD merupakan bagian dari pendidikan nasional. Secara umum, perkembangan dunia pendidikan di Indonesia semakin berkembang pesat, termasuk PAUD. Akan tetapi menurut Laporan Review Kebijakan (DEPDIKNAS:2005), banyak kendala menyertai perkembangan PAUD di Indonesia, terutama dalam hal pendanaan di sektor pendidikan PAUD. Tingkat partisipasi kasar 20\% pada pendidikan, Indonesia menduduki rangking rendah diantara negara yang berpenghasilan rendah. Selain itu pengeluaran biaya pendidikan di Indonesia masih tergolong rendah, dan kondisi ini diperburuk dengan kenyataan bahwa hampir 100\% lembaga PAUD yang ada di Indonesia dikelola oleh swasta dan beban biaya pendidikan dibebankan pada orangtua murid (Sutarman dan Asih:2015). Kondisi ini dapat menyebabkan tidak meratanya kualitas pendidikan, dikarenakan hampir semua sekolah swasta yang berkualitas menekankan pada biaya yang cukup tinggi dan kondisi ini menyebabkan para 
orangtua murid tidak dapat menempatkan putra-putrinya pada sekolah yang berkualitas dan memiliki fasiltas yang memadai.

Sedangkan, pada sebuah literatur menunjukkan hubungan positif antara perkembangan akademik sosial anak-anak prasekolah saat ini dan jangka panjang serta pengalaman mereka dalam sekolah yang berkualitas tinggi, dan dihubungkan dengan anak-anak dari keluarga berpenghasilan rendah (National Institute of Child Health and Human Development Early Child Care Research Network: 2000;National Research Council:2001; Schweinhart: 2005 (dalam Geoffrey Gilbert:49)). Beberapa penelitian membuktikan bahwa anak-anak yang lahir dari kalangan ekonomi tinggi dan bersekolah pada sekolah yang berkualitas tinggi memiliki kesiapan akademik yang lebih baik dan memilki prestasi akademik yang lebih baik pula dibanding anak-anak yang lahir dari kalangan ekonomi rendah. Yang dimaksud dengan kualitas PAUD adalah dapat dilihat dari sisi proses di dalam kelas yang indikatornya meliputi, ukuran kelompok yang kecil, rasio guru dan murid yang rendah, dan tingginya level pendidikan pendidik. Sedangkan kualitas lain adalah dalam proses pembelajaran meliputi hubungan positif antara guru dan anak, membangun aktifitas yang tepat serta kurikulum yang tepat, dan dari kedua hal tersebut antara kualitas kelas dan kualitas proses pembelajaran memiliki hubungan yang kuat untuk membentuk PAUD yang berkualitas (National Research Council:2001). Sehingga kedua elemen tersebut harus berjalan beriringan dan seimbang. Berikut hasil identifikasi permasalahan yang muncul dan mempengaruhi kualitas PAUD:

Tabel 1. Identifikasi Masalah

\begin{tabular}{cll}
\hline \multicolumn{1}{c}{ Domain Utama } & \multicolumn{1}{c}{ Masalah yang Muncul } & \multicolumn{1}{c}{ Penyebab } \\
\hline & $\begin{array}{l}\text { Guru yang bekerja lebih lama } \\
\text { serta lebih berpengalaman kurang } \\
\text { menghargai dan toleran terhadap } \\
\text { kebijakan dalam iklim organisasi }\end{array}$ & $\begin{array}{l}\text { Iklim organisasi memiliki } \\
\text { kualitas yang rendah, } \\
\text { dikarenakan kebijakan yang } \\
\text { diterapkan tidak sesuai dengan } \\
\text { situasi saat ini }\end{array}$ \\
& $\begin{array}{l}\text { Guru baru lebih banyak } \\
\text { memikirkan diri sendiri kurang }\end{array}$ & $\begin{array}{l}\text { Keprihatinan yang tinggi } \\
\text { terkait dengan pengajaran, dan } \\
\text { tugas yang diemban }\end{array}$ \\
Iklim Organisasi dan & mempedulikan iklim organisasi & Kurangnya pengetahuan dan \\
Kualitas Proses Kelas & $\begin{array}{l}\text { Guru dengan kualifikasi } \\
\text { pendidikan rendah cenderung } \\
\text { dependen dalam (perencanaan } \\
\text { pembelajaran, pengumpulan } \\
\text { materi, serta manajemen kelas) }\end{array}$ & $\begin{array}{l}\text { sumber daya untuk } \\
\text { meningkatkan pengetahuan } \\
\text { mereka }\end{array}$ \\
& $\begin{array}{l}\text { Pengembangan profesionalisme } \\
\text { guru melalui pelatihan tidak }\end{array}$ & Hanya berfokus pada guru dan \\
berdampak signifikan & tidak memperhatikan iklim \\
dan kualitas kelas
\end{tabular}

\section{Pembahasan \\ Implementasi Peningkatan Kualitas PAUD}

Lembaga pendidikan yang baik diperlukan manajemen yang tepat agar proses pengelolaan pendidikan dapat berjalan dengan baik dan tepat. Tujuan manajemen PAUD adalah agar sistem yang ada di lembaga PAUD dapat berjalan secara efektif dan efesien. Sebuah sistem pendidikan dikatakan efektif dan efesien apabila program kegiatan belajar yang berlangsung didalamnya berfungsi dengan baik dan mencapai tujuan institusional yaitu menuju arah perkembangan sikap, pengetahuan, keterampilan, dan daya cipta yang diperlukan anak sebagai bekal bagi anak untuk menghadapi lingkungannya dimasa sekarang dan masa mendatang.

Sudjud (dalam Sutarman dan Asih:2015) menyatakan bahwa substansi kegiatan manajemen atau pengelolaan pendidikan PAUD dibagi menjadi tiga kegiatan:

1. Perencanaan penyelenggaraan pendidikan usia dini. Perencanaan merupakan kegiatan menentukan hal-hal yang akan dicapai. 
2. Pengaturan merupakan kegiatan mengatur pelaksanaan segala sesuatu yang telah direncanakan untuk mengefektifkan dan mengefesiensikan pendayagunaan sumber pendidikan anak usia dini

3. Pengawasan pelaksanaan rencana penyelenggaraan pendidikan anak usia dini merupakan kegiatan mengecek, mengukur, menilai, sekaligus memperbaiki dan menyempurnakan upaya pendayagunaan sumber-sumber pendidikan anak usia dini

Pengelolaan manajemen pembelajaran yang baik dimulai dengan perencanaan yang bijak dan didukung dengan komunikasi yang baik, adanya inovasi strategi yang mampu membelajarkan anak, dan kondisi lingkungan belajar yang baik sehingga akan menghasilkan hasil belajar anak yang baik pula (Ramdhani, 2014). Proses pengelolaan yang tepat dan baik akan memperlancar proses pembelajaran, dan pengelolaan yang baik dapat membantu guru, kepala sekolah dan lembaga usia dini untuk persiapan akreditasi. Salah satu manajemen yang dapat diterapkan dalam PAUD adalah manajemen level mikro. Perencanaan pendidikan dan manajemen level mikro ini merupakan perencanaan yang memang digunakan untuk penyelenggaran pendidikan di tingkat lembaga sekolah baik formal maupun non formal.

\section{Manajemen Level Mikro dalam PAUD}

Perencanaan berarti tindakan ke arah masa depan untuk mencapai tujuan yang ditentukan melalui penggunaan sumber daya yang tersedia secara optimal. Sebuah perencanaan berada pada tingkatan yang berbeda yaitu makro, meso, mikro dan kelembagaan. Pada tingkat makro, unit perencanaan berada pada lingkup negara, sementara di tingkat meso dapat dilingkup provinsi. Di tingkat mikro perencanaan pendidikan diterapkan pada tingkat kota, desa. Di tingkat kelembagaan perencanaan mikro adalah perluasan dari proses perencanaan meso.

Perencanaan pendidikan tingkat mikro beroprasi di semua level. Hal ini karena fungsi berbagai jenis perencanaan dan beberapa segi yang saling komplementer dan saling berhubungan. Sebagai contoh, tingkat perencanaan makro yang mana target dan prioritas diterapkan pada tingkat pemerintahan. Perencanaan tingkat mikro dapat mengubah target dan prioritas ini dalam pandangan kondisi sosial, budaya dan ekonomi lokal.

Pendekatan perencanaan dan manajemen inter-sektoral, kontribusi semakin pentingnya perencanaan dan manajemen pendidikan tingkat mikro adalah meningkatnya kesadaran nilai pendekatan lintas sektoral dalam melakukan perencanaan. Perhatian untuk memperluas cakupan perencanaan dan pengelolaan reformasi pendidikan di tingkat lokal, dilatar belakangi oleh pertimbangan:

1. Kebutuhan untuk memperluas pendidikan, membutuhkan hubungan yang efektif dengan berbagai sektor pembangunan.

2. Konsep terus berkembang dari proses pendidikan itu sendiri yang membutuhkan: sistem formal, sektor fungsional, pendidikan non-formal dan informal, pelatihan dan belajar dengan implikasi untuk struktur, konten, metodologi baru.

3. Ketidak mampuan, di satu sisi, dari sistem pendidikan formal saja untuk menyediakan operasionalisasi konsep kesetaraan kesempatan pendidikan, kebutuhan di berbagai sektor pembangunan untuk memenuhi persyaratan

4. Pentingnya keterlibatan masyarakat lokal dalam berbagai tahapan pra-perencanaan, perencanaan, manajemen dan asimilasi pengembangan pendidikan.

Perencanaan dan manajemen tingkat mikro memilki beberapa keuntungan. Berdasarkan

UNESCO (1991) menjabarkan, perencanaan dan manajemen tingkat mikro menekankan pada pedekatan lintas sektoral untuk mengembangkan program masing-masing dalam memberikan kontribusi yang kondusif. Keuntungan Perencanaan Pendidikan Tingkat Mikro:

1. Pengenalan perencanaan pendidikan tingkat mikro tergantung perencanaan dan pelaksanaan bagian lokal dengan keterlibatan dan program yang dilaksanakan

2. Rencana Pendidikan disiapkan di tingkat mikro lebih peka dan responsif dengan kebutuhan lokal dan masalah rakyat.

3. Perencanaan pendidikan di tingkat mikro dapat membantu masyarakat yang berada dalam kendali urusan untuk mempertimbangkan kembali, menyusun kembali dan mengubah rencana dikeadaan sosial budaya, politik, ekonomi dari masyarakat yang dilayani 
4. Perencanaan pendidikan tingkat mikro memungkinkan manajemen lokal yang dalam pelaksanaannya fokus pada kebutuhan khusus dan bervariasi dari bagian yang lebih kecil dari masyarakat.

5. Tingkat mikro dapat memastikan kedekatan diperlukan antara perencanaan dan pelaksanaannya.

6. Dalam konteks perencanaan pendidikan tingkat mikro, ketika orang-orang berinteraksi satu sama lain,sering mengarah ke arah rasa kesatuan dan homogenitas

7. Karena orang lebih cenderung berkomitmen untuk pelaksanaan rencana dirumuskan di tingkat mikro, situasi secara otomatis dapat menyebabkan mobilisasi sumber daya yang sudah ada dan generasi sumber daya lokal baru ke tingkat optimal.

8. Perencanaan pendidikan tingkat mikro juga berfungsi sebagai sarana pendidikan lanjutan bagi hidup masyarakat.

9. Perencanaan pendidikan tingkat Micro lebih lanjut dapat melayani penyebab pendidikan masyarakat dengan membuka jalan bagi pendidikan umum, seperti pendidikan formal dan non-formal. Hal ini lebih mungkin untuk menciptakan suasana menyenangkan bagi pendidikan seumur hidup.

Melalui manajemen mikro diharapkan semua kelompok masyarakat dapat mengenyam pendidikan yang berkualitas dikarenakan manajemen mikro juga melihat bagaimana kebutuhan masyarakat lokal dan hal tersebut dapat dikembangkan untuk semua bidang dan wilayah dengan melibatkan masyarakat sekita untuk turut serta berkontribusi dalam proses pendidikan.

\section{Pengorganisasian Iklim Pendidikan}

Pengorganisasian iklim didefinisikan sebagai suasana yang berbeda dan unik dalam sebuah lembaga pendidikan yang menjadikan kondisi ini sebagai karakter sekolah (Dennis dan O'Connor: 2012). Dan pengorganisasian iklim meliputi persepsi kolektif, tingkah laku, kepercayaan, dan nilai dari masing-masing individu dalam lingkungan kerja, dan kualitas hubungan satu dengan yang lain (Bloom, Hentschel, dan Bella;2010). Pengorganisasian iklim pendidikan ini dapat berpengaruh terhadap kualitas sebuah lembaga pendidikan, dikarenakan penciptaan suasana dan ikatan antar rekan kerja penting dan dibutuhkan alam lingkungan kerja.

Bloom (2010) menjelaskan 10 dimensi pengorganisasian iklim atau lingkungan kerja yaitu meliputi:

1. Kolegialitas (menjalin hubungan kerja dengan baik)

2. Adanya pertumbuhan profesionalisme

3. Dukungan pengawasan

4. Kejelasan atau transparansi

5. Penghargaan kerja

6. Pengambilan keputusan

7. Kesepakatan dalam tujuan

8. Orientasi terhadap tugas yang jelas

9. Pengaturan tenaga kerja

10. Inovasi dalam pendidikan

Sedangkan Hoy dkk (1991) mengidentifikasi hubungan antar individu didalam sekolah yaitu meliputi, hubungan dengan kepemimpinan seperti, dukungan secara langsung, dan adanya batasan tertentu, hubungan antar guru secara dekat dan lain sebagainya. Berdasarkan hasil penelitian disebutkan bahwa pengorganisasian iklim didalam sekolah merupakan ciri terbaik untuk mengetahui atau mengukur kualitas sekolah (Dennis dan O'Connor:2012). Didalam sekolah adanya pengorganisasian iklim dapat mempengaruhi perilaku dan sikap guru, yang mana berdampak pada kualitas kelas dan peningkatan kualitas peserta didik.

Interaksi guru dengan anak merupakan sumber yang dapat membantu perkembangan sosial, perilaku, dan perkembangan kognitif anak pda masa awal usia perkembangan mereka saat disekolah. Titik awal untuk mengkonseptualisasikan domain interaksi gur-anak adalah dengan menempatkan studi tentang hubungan orang dewasa dan anak dalam kerangka teori sistem perkembangan (Bronfenbrenner dan Morris:1998). Dalam hal ini, hubungan guru-anak merupakan sistem diadik yang didalamnya meliputi unsur psikologi, perilaku, biologis, budaya, 
dan proses sementara. Sistem diadik ini berlaku pda tingkat umum dengan melibatkan interaksi antar guru dan anak dalam proses interaksi yang mendorong perkembanagn. Diluar sifat interaksi umum ini memilki dampak untuk anak-anak. Dengan danya interaksi yang intens antara guru dan anak dapat meningkatkan kemampuan literasi anak dan kesiapan akademik anak.

Berdasarkan hasil penelitian ditemukan bahwa iklim yang positif yaitu adanya hubungan emosi, interaksi sosial, dan komunikasi positif antara guru dan anak yaitu berupa kontak mata, adanya percakapan antar guru dan anak dapat memberikan dukungan motivasi dan memunculkan komunikasi yang lebih positif (Hamre, Pianta, Hatfield, dan Jamil:2014). Selain itu, regulasi diri anak berkembang lebih baik, regulasi diri meliputi kontrol diri, dan proses kerja memori anak.

Melihat masalah yang muncul bekaitan dengan iklim organisasi dan kualitas pengelolaan kelas, bahwa masalah muncul dari pendidik dan tenaga kependidikan. Maka solusi yang ditawarkan yakni:

1. Dari permasalahan tersebut jika dikaitkan dengan manajemen pendidikan tingkat mikro maka sebuah lembaga harus memiliki seorang supervisor yang bertugas melakukan monitoring, inspeksi, dan pengawasan terhadap kinerja pendidik dan tenaga kependidikan. Monitoring merupakan bagian dari manajemen umum. Tujuan utama dari sistem monitoring adalah untuk mengembangkan cara yang efektif untuk mengumpulkan informasi dan melaporkan kemajuan pelaksanaan dan status masukan sumber daya dan pemanfaatan dalam program pendidikan yang dilaksanakan. Adapun saat muncul masalah supervisor dapat mengidentifikasi sehingga langkah perbaikan yang diperlukan dapat diambil.

2. Berdasarkan hasil identifikasi masalah yang ada sebaiknya:

a. Kepala sekolah melakukan pertemuan bulanan dengan guru untuk saling memberi masukan baik berkaitan dengan manajerial ataupun berkaitan dengan pembelajaran

b. Kepala sekolah memberikan masukan pada guru berkaitan dengan pengalaman dan eksperimen yang dilakukan guru didalam kelas, dan kepala sekolah memberikan tanggapan bagaimana sebaiknya

c. Memberikan motivasi pada guru untuk membaca literatur yang baik untuk meningkatkan kualitas pendidikan

d. Menjadwalkan guur untuk membaca bergiliran diperpustakaaan

e. Memebuat forum diskusi, worksop dengan guru untuk membahas jurnal, artikel dan lain sebagainya untuk saling bertukar pengalaman dan pengetahuan

f. Melakukan evaluasi dan pengontrolan kemajuan diakhir tahun pembelajaran

g. Memberikan pelatihan guru yakni, memperbarui metode pembelajaran guru melalui mengajak melihat video, mendengarkan radio dan lain-lain. Memberikan seminar, kursus, atau kegiatan lain yang serupa. Mengadakan worksop khusus, seperti pengembangan kurikulum, menulis modul, membuat media visual dan lain-lain

\section{Simpulan dan Saran}

Menjadikan sebuah lembaga pendidikan yang berkualitas merupakan sebuah tantangan dan cita-cita yang luhur. Lembaga pendidikan sebagai peletak pondaasi pertama dan pencetak generasi masa depan bangsa sudah seharusnya memberikan pelayanan yang sebaik-baiknya, dan untuk menjadikan lembaga pendidikan yang berkualitas diperlukan kerjasama dari berbagai unsur, perencanaan yang baik serta pengelolaan yang tepat. Berdasarkan penjelasan diatas dapat diambil dua kesimpulan bahwa terdapat dua faktor yang dapat menjadikan lembaga pendidikan yang berkualitas adalah adanya keseimbangan dalam proses pengelolaan pendidikan dan pengorganisasian iklim didalam proses pendidikan baik dalam proses pembelajaran maupun dalam lingkungan kerja.

Dua unsur tersebut dapat mendukung dan berkontribusi besar dalam menjamin kualitas pendidikan khususnya pendidikan anak usia dini. Serta salah satu cara agar pendidikan terlaksana secara merata diperlukan perencanaan dan manajemen yang tepat salah satunya menggunakan manajemen tingkat mikro. Manajemen tingkat mikro tepat diterapkan dalam 
PAUD dan melalui manajemen mikro dapat memberikan pelayanan yang berkualitas pula bagi anak-anak yang lahir dari keluarga dengan tingkat ekonomi rendah.

\section{Daftar Rujukan}

1991. Micro-Level Education Planning and Management. Bangkok: UNESCO

Arikunto Suharsimi, \& Yuliana Lia. 2009. Manajemen Pendidikan. Yogyakarta: Aditya Media Yogyakarta

Bloom P.J, Hentschel A, dan Bella. (2010). A Great Place to Work: Creating a Healthy Organitational Climate. Lake Forest: New Horizons

Bronfenbrenner U, dan Morris P.A. (1998). The Ecology of Developmental Processes. Handbook of Child Psychology: Vol 1. New York: J. Wiley

Dennis S.E, dan O'Connor E. (2013). Reexamining Quality in Early Childhood Education: Exploring the Relationship Between the Orgabizational Climate and The Classroom. Journal Research in Childhood Education, 27(1), 74-92. doi: 10.1080/12568543.2012.739589

Gilbert, G. (2008). Rich and poor in America: A reference handbook. Santa Barbara, CA: ABCCLIO.

Hamre B, Pianta R, Hatfield B, dan Jamil F. (2014). Evidence for General and Domain-Spesific Elements of Teacher-Child Interaction:Association With Preschool Children's Development. Child Development, 85(3),1257-1274. doi: 10.1111/cdev. 12184

Hoy W. K., Tarter, C. J., dan Kottkamp R. (1991). Open schools/healthy schools: Mea-suring organizational climate. Newbury Park, CA: Sage

Ramdhani, M. A., dan Ramdhani, A. (2014). Verification of Research Logical Framework Based on Literature Review. International Journal of Basic and Applied Science, 03(02), $1-9$.

Suryaman. (2004). Budaya Organisasi di Sekolah. Jurnal Buana pendidikan, tahun 1, No. 1. Oktober 2004. ISSN 1693-8585.

Sutarman Haman dan Asih. (2016). Manajemen Pendidikan Usia Dini Filosofi, Konsep, Prinsip dan Aplikasi. Bandung :PUSTAKA SETIA Undang-undang No. 20 tahun 2003 tentang Sistem Pendidikan Nasional

UNESCO. (1991). Micro Level Educational Planning and Management. Bangkok: UNESCO PROAP 